\title{
Analysing Physical Condition of Central Sulawesi Delegates for PON XIX with Medal Awards
}

\author{
Humaedi \\ Faculty of Teacher Training and Education \\ University of Tadulako \\ Palu, Indonesia \\ hum771@gmail.com
}

\begin{abstract}
This research aims at analyzing the level of physical condition with the possession of medal of Central Sulawesi contingent on XIX national sports event in 2016 at West Java. The purpose of this research is to describe the physical condition and medal position as the inputs for sports education both in the secondary Scholls and university level. The method used in this research is testing and measuring physical condition of the contingent that consists 89 participants who participate in Regional Training Center in 2016. Based on the test result, it is found that there are no athletes with the very good physical condition, 20 athletes in good condition, 51 athletes in fair condition, 16 athletes in poor condition, and 2 athletes in very poor condition who participate in IX national sports event in 2016 at West Java. This research was conducted at National Sports Committee (KONI) May to August 2016 in West Java. The finding of this research indicates that there are 7 athletes or $35 \%$ out of 20 received medals. 13 athletes or $25,49 \%$ out of 51 with a fair level of physical condition received 6 medals. Athletes with poor physical condition presented 1 medal or $6,25 \%$ out of 16 athletes received 1 medal.
\end{abstract}

Keywords- Physical condition, Central Sulawesi Athletes, Sport Education

\section{INTRODUCTION}

The physical condition of the athlete plays an important role in supporting the improvement of the achievement of a sport. The condition is determined by quality of training while the training quality has a positive influence towards performance of the athletes. The main purpose of physical preparation is to increase functional potential of athletes and develop bio motoric ability to highest standard, [1]

Benchmark for the success of sports coaching in the main sport organization in the level of Central Sulawesi province is : (1) rank occupied on the PON, (2) the number of athletes in Central Sulawesi which represent the Indonesian contingent to the SEA Games, Asian Games and Olympic Games as well as achievement for Indonesia, (3) the success of Central Sulawesi athletes in the national championship, and (4) the success in achieving record or a record-breaking PORPROV (Provincial Sports week) or nationally. The benchmarks can be seen in Central Sulawesi sporting achievements in obtaining medals in each KEJURNAS or PON, Central Sulawesi always occupies the bottom position. The following table is the number of medals and ranking of Central Sulawesi in the last 3 PON.
TABLE I. MEDAls COUNT AND RANKING OF CENTRAL SUlAWESI IN THE LAST 3 PON

\begin{tabular}{|c|l|c|c|c|c|}
\hline \multirow{2}{*}{ No } & \multicolumn{1}{|c|}{ PON } & \multicolumn{3}{|c|}{ Medals Won } & \multirow{2}{*}{ Level } \\
\cline { 2 - 5 } 1 & $\begin{array}{l}\text { XVI 2016 } \\
\text { Palembang }\end{array}$ & 1 & 5 & 4 & $\begin{array}{c}\text { XXVII } \\
\text { I }\end{array}$ \\
\hline 2 & $\begin{array}{l}\text { XVII 2008 East } \\
\text { Kalimantan }\end{array}$ & 0 & 3 & 6 & XXXI \\
\hline 3 & $\begin{array}{l}\text { XVIII 2012 } \\
\text { Riau }\end{array}$ & 1 & 1 & 1 & XXX \\
\hline
\end{tabular}

In the preparations for the PON XIX in 2016 in West Java, Indonesian National Sports Committee (KONI) of Central Sulawesi has set up a priority policy with a very tight evaluation to capture sports and athletes who will be participated as a contingent of Central Sulawesi, thus funding and other resources can be utilized effectively and efficiently.

Determination of physical condition level as a reference to establish whether or not an athlete can be sent to participate in the arena of PON XIX in West Java is possible because participation in the arena is always associated with the intended targets namely medals.

However, whether of not sufficient level of physical conditions to attend an event such as PON XIX in West Java can guarantee that an athlete can win a medal as expected. This will become a major concern in this study entitled "Analysis of Physical Condition of Central Sulawesi contingent With Medals Won at PON XIX in West Java, 2016.

The problem of this study is as follows: how many athletes who have a good and a fair level of physical condition can win medals for Central Sulawesi contingent in PON XIX, 2016.

The results of this study can benefit KONI in Central Sulawesi in the way that it can become a reference or considerations for sending athletes especially in deciding whether or not they can take participate in PON or other championships, coaches are becoming a standard in preparing the athletes, especially in physical exercise to improve the physical condition of athletes in facing every championship and a teacher of Physical Education is also a good reference to provide information for students and coach them in pursuing a specific sport that becomes an extracurricular activity at school. 
The physical condition of athletes plays an important role in supporting the achievement of a sport. The increased physical condition of athletes is determined by the quality of training. Ref. [2] argues that: "Training is the implementation of a plan to develop the ability to in sport that contains theory and practice, the methods and rules of engagement." Meanwhile, [3] states "Definition of exercise that is derived from the word exercise is the main device in the process of daily practice to improve the quality of human organs function making it easier for sportsmen in the completion of the motion."

The main goals and objectives of an exercise are to help athletes improving their skills and the athlete's performance as much as possible. Ref. [4] suggests that: "Exercise factor is one of the factors that can affect the level of physical fitness or physical condition". So exercise physical condition is very important in improving the athlete's performance. Ref. [5] adds "The physical condition exercise is a process to develop the ability of movement of physical activity carried out systematically and be progressively increased to maintain and increase the degree of physical fitness." Exercise that is done repeatedly, then slightly increased in intensity and complexity, will eventually turn athletes into a stronger person, have resilience, more agile, more skilled and more effective movements displayed according to his expertise. Ref. [6] puts it that: " Process of Physical exercise that is done repeatedly with an increased intensity allows a person to become skilfull, stronger, and efficient in movement."

Elements of the physical condition include strength, speed, flexibility, agility, coordination, endurance, explosive power, accuracy and reaction. According to [7], power is maximum force or rotation force generated by a muscle or group of muscles." These elements are general conditioning that is needed to achieve peak physical condition in order to support the further exercise. Not all sports require optimal improvement of the physical elements.

Each sport has specific conditioning that needs to be optimally developed to support the implementation of the sports technique. In this study several physical elements that act as general physical condition and specific physical condition to various sports and becoming basic physical component measured in determining the physical condition of Central Sulawesi athletes which will be sent to PON XIX in West Java. These physical elements include strength, muscular endurance, power limbs, reaction speed, flexibility, agility and maximum oxygen capacity (V02max).

Achievement is a manifestation of talent and ability. Highest achievement reflects the superior talent in a person. But a talented person does not necessarily reach highest achievement because there are other factors that can determine individual achievement in the form of external factors, such as opportunities, facilities and infrastructure, the support of parents, socioeconomic level and largely determined internal factors are the desire of achievement, perseverance to overcome difficulties and motivation to excel.

With very good, good, fair, physical condition, it can be predicted that athletes can win medals for Central Sulawesi contingent at PON XIX.

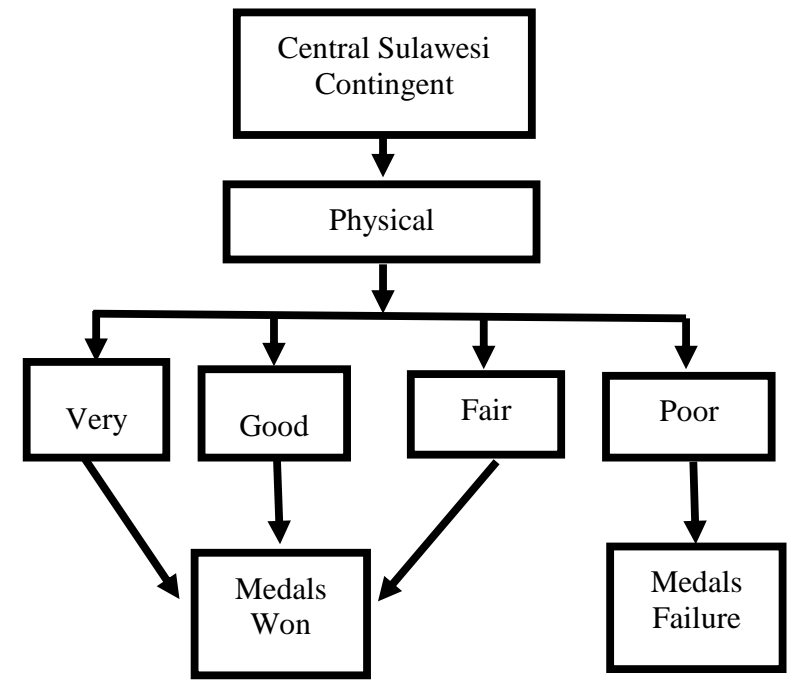

Fig. 1. Theoretical Framework

\section{METHOD}

This study is a qualitative descriptive study conducted by Indonesian National Sports Committee (KONI) located in Central Sulawesi, Palu.

Variables of this research (1) level of the physical condition according to its level: very good, good, fair, and poor (2) Medals won by Central Sulawesi contingent at PON XIX in West Java 2016.

The population in this study is 89 athletes who competed in the National Games XIX in West Java in 2016. While the sample of this study is 89 athletes, consisting of 67 males and 22 females who took part in Pelatda and medalist at the National Games XIX in West Java.

The research instrument used is physical tests by providing chances to athletes to perform well and its results become researcher's confidentiality, and documentation because this study is results of evaluation towards athletes who undertook PON XIX preparation and medals won at PON XIX. Data on physical condition that had been collected at PON XIX West Java, 2016.

In this study, researcher employed a descriptive analysis design technique with percentage technique of the number of athletes who won medals according to their physical condition category

\section{RESULTS AND DISCUSSION}

Data on physical condition measurement of PON XIX athletes from Central Sulawesi then compared with the medal won by athletes from Central Sulawesi at PON XIX in Bandung, West Java. All athletes of PON XIX that have been analyzed involved all athletes who won medal including team sport and individual sport.

The total number of medals won by a contingent of Central Sulawesi at PON XIX were 11 medals, consisted of 4 silver 
medals and 7 bronze medals obtained from 7 different sports that won by 13 athletes.

TABLE II. Summary OF PERCENTAGE of CENTRAL Sulawesi ATHLETES WHO PARTICIPATED IN PON XIX 2016 BASED ON THE LEVEL OF PHYSICAL CONDITION

\begin{tabular}{|c|l|c|c|}
\hline No & \multicolumn{1}{|c|}{$\begin{array}{c}\text { Level of physical } \\
\text { condition }\end{array}$} & $\begin{array}{c}\text { Number of } \\
\text { athletes }\end{array}$ & $\%$ \\
\hline 1 & Very Good & - & - \\
\hline 2 & Good & 20 & 22.47 \\
\hline 3 & Fair & 51 & 57.30 \\
\hline 4 & Poor & 16 & 17.98 \\
\hline 5 & Very Poor & 2 & 2.25 \\
\hline \multicolumn{2}{r|}{ Total } & 89 & \\
\hline
\end{tabular}

Table II shows that category of physical condition who participated in PON XIX 2016. None of the athletes have the very good physical condition. 20 athletes or $22.47 \%$ were in good physical condition. 51 athletes or $57.3 \%$ were in the fair category, and 2 athletes or $2.25 \%$ were in the poor condition.

\section{DISCUSSION}

The first analysis results showed that 20 out of 89 athletes, seven athletes or $35 \%$ out of 20 athletes won 6 medals, 4 medals ( 3 silver medals and 1 bronze medals) from individual sports and 2 medals from team sports.

The second analysis result showed 51 athletes or 57.3 on the category fair on their physical condition. Thirteen (13) athletes won six medals, 4 medals ( 1 silver medals and 5 bronze medals) from individual sports and 2 medals from team sports.

The third analysis result showed that 16 athletes or $17.98 \%$ on the poor physical condition who participated in PON XIX 2016. One of the athletes won a medal. The athlete was a member of sepak takraw team.

\section{CONCLUSIONS}

A contingent of Central Sulawesi on PON XIX 2016 in West Java consisted of 7 out of athletes or $35 \%$ in good physical condition and won 6 medals (3 silver medals and 3 bronze medals). There were 13 Athletes or $25.49 \%$ on the fair physical condition won 6 medals ( 1 silver medals and 5 bronze medals). 16 athletes or $17.98 \%$ on the poor physical condition and won 1 bronze medal in group sports category.

In order to obtain the maximal result (gold medal) in sports competition, it needs to improve the physical condition of the athletes from fair condition into very good condition. Longterm coaching program can be one of the ways to achieve the goal and it needs to know the initial physical condition before the athletes joining the program. One of the indicators to know whether the training program improves skills and competency of the athletes.

It is expected that physical education study program will able to provide input and suggestion to Indonesian National Sports Committee (KONI) of Central Sulawesi, trainers as well as teachers of physical education to consider the importance of physical condition in the coaching of sports.

\section{REFERENCES}

[1] Tudor O. Bompa. Periodization, Theory and Methodology of Training, York Univesity: Human Kinetics, 2009, pp. 57

[2] Sukadiyanto. Pengantar Teori dan Metodologi Melatih Fisik. Bandung: CV. Lubuk Agung, 2011, pp. 34-35

[3] G. Wiarto. Fisiologi dan Olahraga. Yogyakarta: Graha I, 2013, pp. 45-47

[4] M. Annas. "Profil Tingkat Kesegaran Jasmani Mahasiswa PJKR Jalur Undangan tahun 2012/2013." Jurnal Pendidikan Olahraga. Vol. 1 (1), pp. 1-7, Feb. 2014

[5] S. Hidayat. Pelatihan Olahraga. Yogyakarta: Graha Ilmu, 2014, pp. $37-$ 38

[6] Ruslan. "Meningkatkan Kondisi Fisik Atlet Pusat Pendidikan dan Latihan Olahraga Pelajar (PPLP) di Provinsi Kalimantan Timur". Jurnal ILARA II. Vol. 2, pp. 45-56. Aug. 2011.

[7] J. Lubis.’Latihan Kekuatan Atlet Muda.” Jurnal JUARA. vol. 1, pp. 5580,2013 